\title{
Effect of acidic and basic pretreatment of wild algal biomass on Cr (VI) biosorption
}

\author{
Shailendra Kumar Singh, Kritika Dixit and Shanthy Sundaram \\ Centre of Biotechnology, University of Allahabad, Allahabad, Uttar Pradesh, India - 211002
}

\begin{abstract}
In the present study, effect of acidic and basic pre-treatment of wild algal biomass for their hexavalent chromium removal capacity was investigated. Wild algal biomass was subjected to chemical pretreatments with acid (perchloric acid with formaldehyde in 1:1 ratio $(P F)$ ), base $(0.5 \mathrm{~N} \mathrm{NaOH})$, and only distilled water washed $(D W)$. Batch experiments were conducted to determine the adsorption properties of pretreated wild algal biomass. It was observed that biomass was capable of removal of $\mathrm{Cr}(\mathrm{VI})$ metal ions from aqueous solution. The removal percentage was significantly depends on contact time, equilibrium $\mathrm{pH}$, initial metal concentration and biosorbent load. Removal equilibrium was attained in less than 2 hours. Optimum $\mathrm{pH}$ for $\mathrm{Cr}(\mathrm{VI})$ was found to be $2 \mathrm{pH}$, and optimum algal dose was $10 \mathrm{~g} / \mathrm{L}$. It was also observed that removal percentage was increased after acidic pre-treatment of wild algal biomass. In contrast, it was decreased significantly after basic pre-treatment. The order of maximum metal uptakes for $\mathrm{Cr}(\mathrm{VI})$ was $\mathrm{PF}>\mathrm{DW}>\mathrm{NaOH}$. The sorption data of DW obtained at pH 2.0 conformed well fitted in both Langmuir and Freundlich isotherm models $\left(R^{2}>0.99\right)$. The study concluded that the algal biomass pre-treated with perchloric acid and formaldehyde is more efficient biosorbent than sodium hydroxide pretreated algae and raw algae biomass for solution containing hexavalent chromium.
\end{abstract}

Keywords: Algae, Biosorption, Heavy metal, Pollution

\section{Introduction}

Rapid and unorganized urban and industrial developments have contributed continuously to the elevated levels of heavy metals which depleting natural resources and deteriorating the environmental quality [1]. About 90 per cent of sewage and 70 per cent of industrial wastes in developing countries are discharged untreated or partially treated wastes into water courses [2]. There are several technologies for treatment of wastewater like reverse osmosis, electrodialysis, ultrafiltration, chemical precipitation, ion exchange and phytoremediation are commonly used in industries. However, these technologies are often expensive, generating toxic non eco-friendly sludge or other waste products that require careful disposal and ineffective when the metals concentration are low (range 1-100 mg.L ${ }^{-1}$ ) [3]. During the last few decades, biosorption process has emerged as an alternative solution of conventional technologies for the removal of toxic metals from water/wastewater [4]. Among promising biosorbents, algae have been found to be effective biosorbent due their huge abundance and high metal uptake capacities. Metal sorption capacity of biosorbent can be altered by pretreatment. The various chemical treatments used for biomass modification include washing the biomass with detergents, cross-linking with organic solvents, and alkali or acid treatment. The pretreatment could modify the surface characteristics either by removing or masking the groups or by exposing more metal-binding sites [5]. In the present study, the effect of pretreatment on metal uptake capacity of biosorbent for the different pretreatment methods used has been studied. Wild algae was chemically modified by acidic (perchloric acid with formaldehyde (PF), basic pretreatments $(\mathrm{NaOH})$, or only washed by distilled water (DW).

\section{Material And Methods}

Bioabsorbent processing: Wild algae samples were collected from native water reservoirs. Algal biomass was dried in an oven at $60{ }^{\circ} \mathrm{C}$ to constant weight, grind and sieved with the help of $85 \mathrm{BSS}$ sieve. The $0.18 \mathrm{~mm}$ particle size fraction of biomass was used through the experiments.

Pretreatment: For basic pretreatment, $50 \mathrm{~g}$ wild algae was mixed with $500 \mathrm{ml}$ solution of $0.5 \mathrm{~N} \mathrm{NaOH}$ in $1000 \mathrm{ml}$ beaker. The mixture was stirred with the help of magnetic stirrer for 8 hours and then centrifuged and washed with distilled water. For acidic pretreatment, $100 \mathrm{~g}$ of wild algae was mixed with perchloric acid $\left(\mathrm{HClO}_{4}\right)$ and formaldehyde $(\mathrm{HCHO})$. $(25+25) \mathrm{ml}$ equal v/v of $\mathrm{HClO}_{4}+\mathrm{HCHO}$ diluted to $1000 \mathrm{ml}$ of distilled water. The mixture was stirred with the help of magnetic stirrer for 8 hours and then centrifuged and washed with distilled water to remove excess $\mathrm{ClO}_{4}{ }^{-}$and aldehyde. For blank sample, wild algae was washed simply with distilled water and dried at $60{ }^{\circ} \mathrm{C}$. All of the dried pretreated algae samples were preserved at $4{ }^{\circ} \mathrm{C}$ for future use.

Chromium detection: The residual concentrations of chromium (VI) in the aqueous solution were determined using diphenyl carbazide method [6] at $540 \mathrm{~nm}$ using spectrophotometer. The pink colored complex, formed from 1, 5-diphenylcarbazide and $\mathrm{Cr}$ (VI) in acidic solution, was able to be spectrophotometrically 
analyzed at $540 \mathrm{~nm}$. To measure total $\mathrm{Cr}$ concentration, the $\mathrm{Cr}$ (III) was first converted to $\mathrm{Cr}$ (VI) at high temperature $\left(130-140{ }^{\circ} \mathrm{C}\right)$ by the addition of excess potassium permanganate prior to the 1,5-diphenylcarbazide reaction. The $\mathrm{Cr}$ (III) concentration was then calculated by subtracting the $\mathrm{Cr}$ (VI) concentration from the total Cr concentration.

Biosorption experiments: Batch experiments were performed in $250 \mathrm{ml}$ Erlenmeyer flasks containing $100 \mathrm{ml}$ of $10 \mathrm{mg} / \mathrm{L} \mathrm{Cr}$ (VI) solutions. The experimental set up was incubated on a rotary shaker at $150 \mathrm{rpm}$ at 30 ${ }^{\circ} \mathrm{C}$ for 2-3 $\mathrm{h}$ and biosorbents loaded with adsorb metal separated from solution by filtration. Sorption process parameters such as adsorption time, metal concentration, initial $\mathrm{pH}$ values and biosorbent load were optimized. The $\mathrm{pH}$ of each solution was adjusted with $0.1 \mathrm{~N} \mathrm{NaOH}$ and $\mathrm{HCl}$. The percent biosorption of metal ion was calculated as follows:

$$
\text { Percentage removal }(\%)=\frac{C_{1} C_{i}}{d} \times 100
$$

Where, $\mathrm{C}_{\mathrm{i}}$ and $C_{\mathrm{f}}$ are initial and final concentrations of metal ions, respectively.

The biosorption capacities were evaluated using Langmuir and Freundlich isotherms [7].

\section{Results And Discussion}

Effect of contact time: The sorption studies at different contact times help in determining the sorption capacities of biomass at varying time intervals. The effect of contact time on the percentage removal of $\mathrm{Cr}$ (VI) from synthetic solutions with initial metal ion concentration of $10 \mathrm{mg} / \mathrm{l}$ for $\mathrm{Cr}$ (VI) using the algal dose of $10 \mathrm{~g} / \mathrm{l}$ are shown in Figure 1. It can be observed that all of the pretreated samples showed similar trend of removal. A rapid removal of $\mathrm{Cr}(\mathrm{VI})$ took place in the first $30 \mathrm{~min}$, and thereafter the removal became asymptotic. Figure 1 showed a rapid removal of $65 \%$ at $15 \mathrm{~min}$ and remained almost constant to $80-85 \%$ with minute fluctuations. It was attributed the fact that initially all functional groups on biosorbent were vacant and solute concentration was high [8]. However, after 1 hour, very few active sites were left on algal cell wall. Maximum percentage removal of $85 \%$ was achieved within a period of 1-2 hours. Therefore, for all experiments, optimum contact time was taken as 2 hours.

Effect of pH: $\mathrm{pH}$ controls the metal ion dissolution and the magnitude of the electrostatic charge in the medium [9]. It influences both the speciation of $\mathrm{Cr}(\mathrm{VI})$ in the aqueous solution and the binding sites availability on the surface of biosorbent [10]. Effect of $\mathrm{pH}$ on biosorption was studied over a range of 1 to 5. The results indicated that the $\mathrm{Cr}(\mathrm{VI})$ biosorption by non-living cells of algae was affected by initial $\mathrm{pH}$ of the solution and may be due to ionic attraction. Therefore, at low $\mathrm{pH}$ values the cell surface becomes more positively charged, reducing the attraction between metal ions and functional groups on the cell walls. As evident from Figure 2, at initial pH 1.0 nearly $99 \% \mathrm{Cr}(\mathrm{VI})$ was removed. While at initial pH 5.0, 80\% $\mathrm{Cr}$ (VI) could be removed. High percentage removal at low $\mathrm{pH}$ was attributed to the fact that hexavalent chromium may be transformed in to trivalent form at low $\mathrm{pH}$. To verify this speciation assumption, we analyzed the total $\mathrm{Cr}(\mathrm{Cr}$ (VI) and $\mathrm{Cr}$ (III)) concentration in the medium after equilibrium. At low pH high $\mathrm{Cr}$ (III) concentration existed (result not showed) and sharply decreased with $\mathrm{pH}$ increase. It was determined that at $\mathrm{pH} 2$ we have maximum removal efficiency. Acidic pretreatment showed high sorption around $90 \%$ while $\mathrm{NaOH}$ was least with $88 \%$ at $\mathrm{pH} 2$. This may be due to modifications on the cell wall components which remove the surface impurities and expose available active metal binding sites embedded in the cell wall.

Effect of $\mathrm{Cr}(\mathrm{VI})$ concentration and biosorbent load: The initial concentration of metal provides an important driving force to overcome all mass transfer resistance of metal ion between the aqueous and solid phases [11]. Hence, effect of different concentration of chromium ion $(15,20,25$, and $30 \mathrm{mg} / \mathrm{l})$ was studied in conjunction with algal dose $(5,10$, and $15 \mathrm{~g} / \mathrm{L})$ variation as shown in Figure 3. It is clear that the removal of $\mathrm{Cr}$ (VI) depended on the initial metal concentration and biosrbent dose. The $\mathrm{Cr}$ (VI) percentage removal decreases with increase in $\mathrm{Cr}$ (VI) concentration. Higher initial $\mathrm{Cr}$ (VI) concentration increased the number of collisions between $\mathrm{Cr}(\mathrm{VI})$ ions and the adsorbent, which decrease the adsorption process. In contrast, percentage removal of $\mathrm{Cr}(\mathrm{VI})$ increased with the increase of biosorbent dosages due to increased available surface area and number of binding sites. Maximum removal of $96.8 \%$ was observed at an algal dose of $15 \mathrm{~g} / \mathrm{l}$ from the solution with initial $\mathrm{Cr}$ (VI) ions concentration as $15 \mathrm{mg} / \mathrm{l}$.

Biosorption isotherm models: Figure 4 (a) indicates the linear relationship between the amount (mg) of $\mathrm{Cr}(\mathrm{VI})$ ions sorbed per unit mass $(\mathrm{g})$ of biomass against the concentration of $\mathrm{Cr}(\mathrm{VI})$ ions remaining in solution $(\mathrm{mg} / \mathrm{L})$. The coefficient of determination $\left(R^{2}\right)$ was found to be 0.9986 for $\mathrm{Cr}(\mathrm{VI})$ biosorption, indicating that the biosorption of the metal ions onto biomass well fitted the Langmuir model. The $b$ value was found as 0.01568 $\mathrm{L} / \mathrm{mg}$ for $\mathrm{Cr}(\mathrm{VI})$ ion . The maximum biosorption capacity $\left(q_{\mathrm{m}}\right)$ was found to be $7.007 \mathrm{mg} / \mathrm{g}$ for $\mathrm{Cr}(\mathrm{VI})$ ion. The Figure 4 (b) shows the Freundlich isotherms obtained for the biosorption of $\mathrm{Cr}(\mathrm{VI})$ ions onto biomass using Eq. (3). The values of $K_{\mathrm{F}}$ and $1 / n$ were found to be 3.807 and1.0056 for $\mathrm{Cr}(\mathrm{VI})$ biosorption. It can be seen from the value of $\mathrm{R}^{2}$ that both Langmuir and Freundlich model well fitted the equilibrium sorption data. 
IV. Figure And Legend

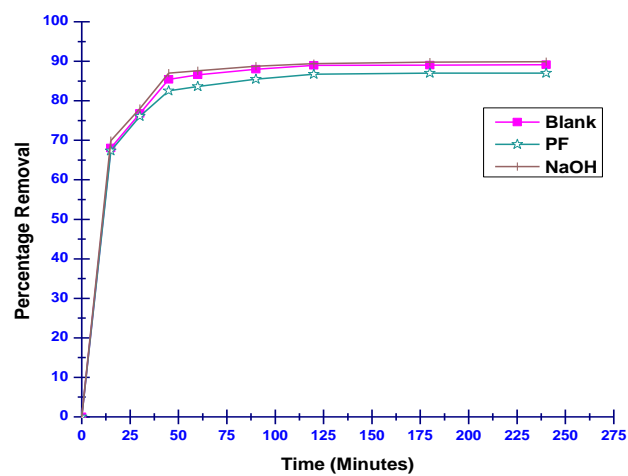

Figure-1: Effect of contact time on biosorption of $\mathrm{Cr}(\mathrm{VI})$

(Metal concentration: $10 \mathrm{mg} / \mathrm{L}$; Biomass dosage: $10 \mathrm{~g} / \mathrm{L}$; $\mathrm{pH}$ : 5 ; temperature $30^{\circ} \mathrm{C}$ ).

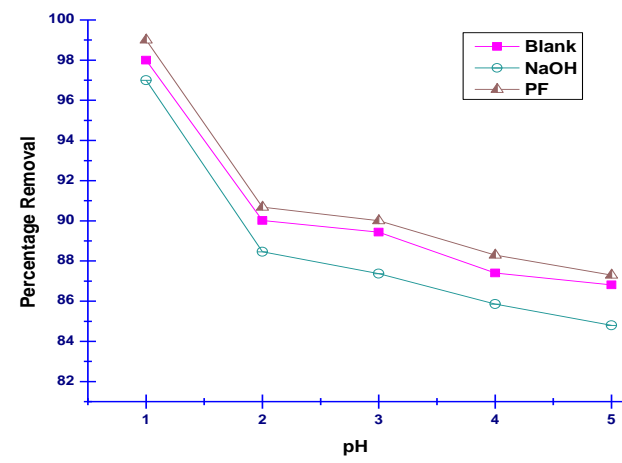

Figure-2: Effect of $\mathrm{pH}$ on biosorption of $\mathrm{Cr}(\mathrm{VI})$ (Contact time: 2 hours; Metal concentration: $10 \mathrm{mg} / \mathrm{L}$; biomass dosage: $10 \mathrm{~g} / \mathrm{L} \mathrm{h}$; temperature $30^{\circ} \mathrm{C}$ ).
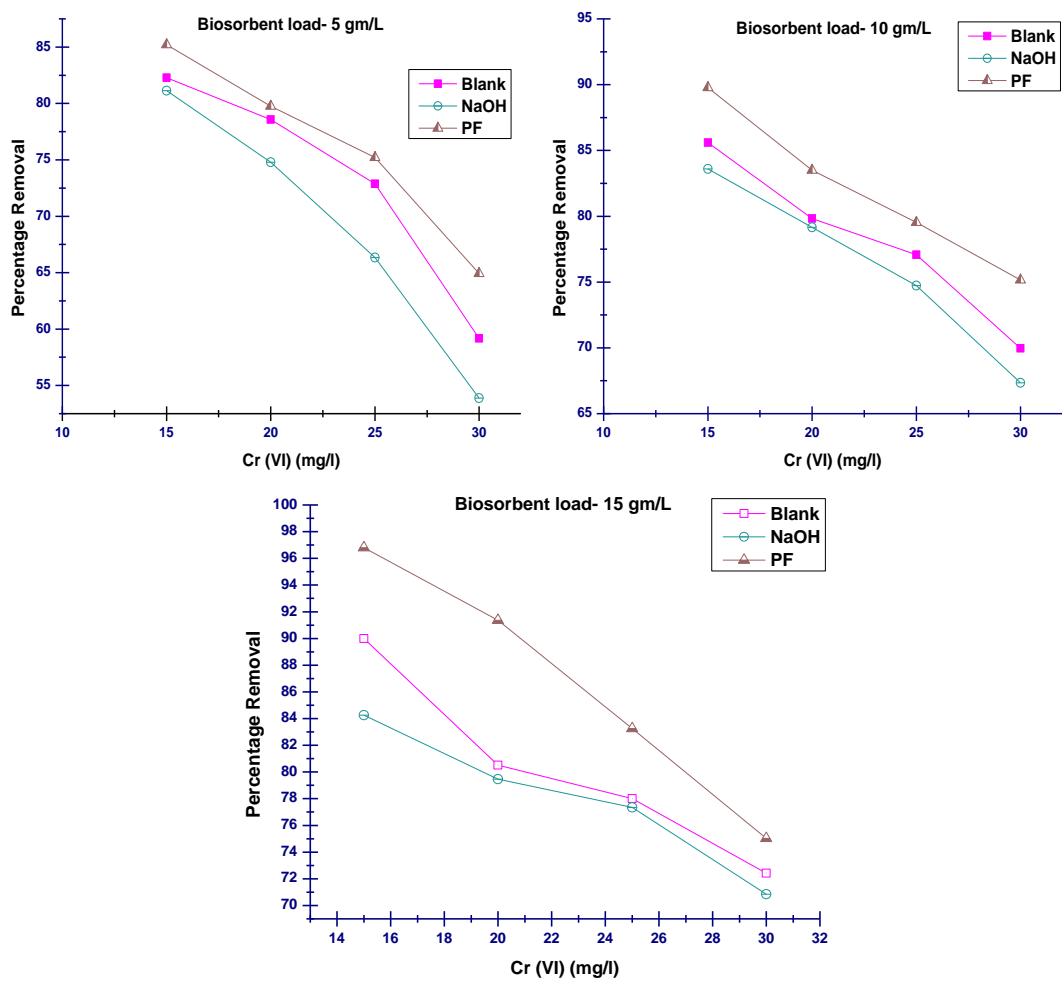

Figure 3. Effect of initial metal concentration (15, 20, 25, and $30 \mathrm{mg} / \mathrm{l})$ and biomass dosage: (a) 5, (b) 10 and (c) $15 \mathrm{~g} / \mathrm{L}$ on $\mathrm{Cr}(\mathrm{VI})$ biosorption (Contact time: 2 hours; $\mathrm{pH}: 2$; Temperature $30^{\circ} \mathrm{C}$ ). 

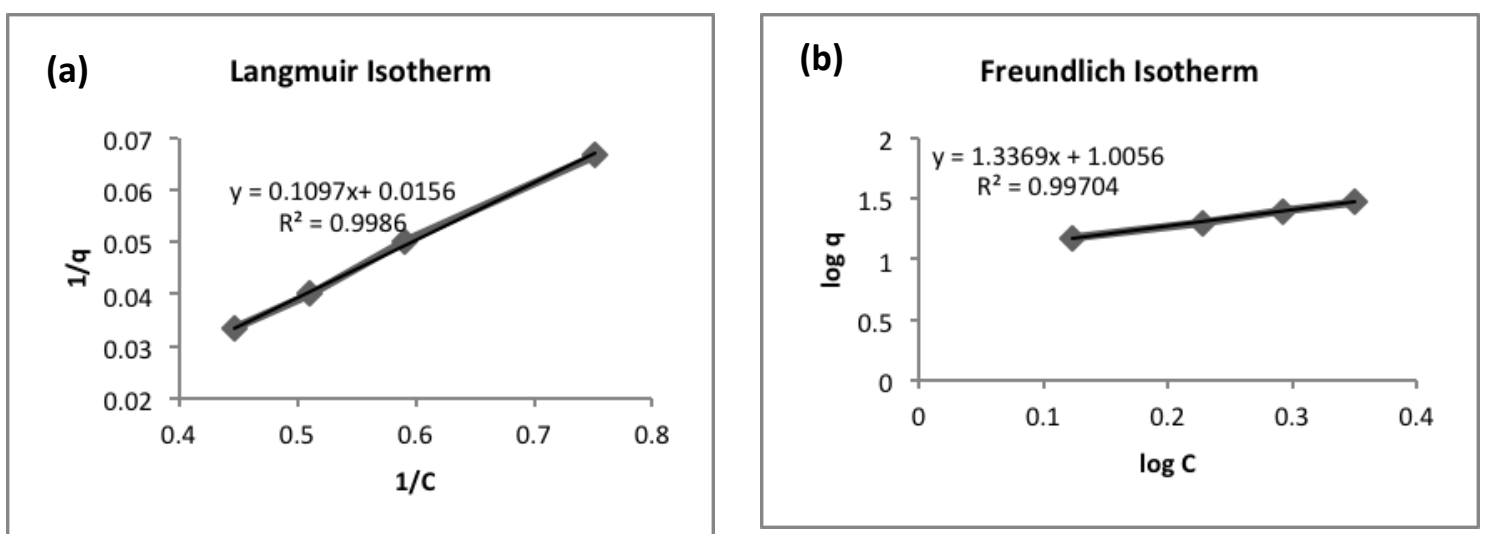

Figure 4. Biosorption isotherms of DW (a) Langmuir (b) Freundlich (Biomass dosage: $10 \mathrm{~g} / \mathrm{L}$; contact time: 2 hours ; $\mathrm{pH}$ : 2 ; temperature: $30^{\circ} \mathrm{C}$ ).

\section{Conclusions}

The effect of acid and basic pretreatment of algae for the removal of chromium has been studied. Results showed that removal efficiency was reduced in sodium hydroxide pretreatment compared to raw algae (DW). However, effect of acidic pretreatment has been studied and we found that by using (perchloric acid+ formaldehyde) for pretreatment the removal efficiency increases as compared to raw algae (DW) and $\mathrm{NaOH}$ treated. The order of maximum metal uptakes for $\mathrm{Cr}(\mathrm{VI})$ was $\mathrm{PF}>\mathrm{DW}>\mathrm{NaOH}$. The coefficients of correlation $\left(\mathrm{R}^{2}\right)$ of both Langmuir and Freundlich model well were fitted the equilibrium chromium sorption data. Moreover, further detailed studies should be conducted in order to clarify the causes of enhancement or decrease in adsorption capacity for wild algal biomasses.

\section{References}

[1]. V.n.L. Colin, L.B. Villegas, and C.M. Abate, Indigenous microorganisms as potential bioremediators for environments contaminated with heavy metals. International Biodeterioration \& Biodegradation 69 (2012) 28-37.

[2]. E. Corcoran, C. Nellemann, E. Baker, R. Bos, D. Osborn, and H. Savelli, Sick Water? The central role of waste-water management in sustainable development. A Rapid Response Assessment. United Nations Environment Programme, UN-HABITAT (2010).

[3]. S.K. Singh, A. Bansal, M.K. Jha, and A. Dey, An integrated approach to remove Cr (VI) using immobilized Chlorella minutissima grown in nutrient rich sewage wastewater. Bioresource Technology 104 (2012) 257-265.

[4]. M. Chiban, M. Zerbet, G. Carja, and F. Sinan, Application of low-cost adsorbents for arsenic removal: A review. Journal of Environmental Chemistry and Ecotoxicology 4 (2012) 91-102.

[5]. R. Gupta, P. Ahuja, S. Khan, R.K. Saxena, and H. Mohapatra, Microbial biosorbents: meeting challenges of heavy metal pollution in aqueous solutions. CURRENT SCIENCE-BANGALORE- 78 (2000) 967-973.

[6]. L.S. Clesceri, A.E. Greenberg, and A.D. Eaton, (Eds.) (1998) Standard Methods for the Examination of Water and Wastewater, APHA, Washington, DC.

[7]. M.D. Levan, and T. Vermeulen, Binary Langmuir and Freundlich isotherms for ideal adsorbed solutions. The Journal of Physical Chemistry 85 (1981) 3247-3250.

[8]. S. Basha, Z.V.P. Murthy, and B. Jha, Biosorption of hexavalent chromium by chemically modified seaweed, Cystoseira indica. Chemical Engineering Journal 137 (2008) 480-488.

[9]. K. Vijayaraghavan, and Y.-S. Yun, Bacterial biosorbents and biosorption. Biotechnology Advances 26 (2008) 266-291.

[10]. R. Swietlik, Speciation analysis of chromium in waters. Polish Journal of Environmental Studies 7 (1998) 257-266.

[11]. E. Bazrafshan, F.K. Mostafapour, A.R. Hosseini, A. Raksh Khorshid, and A.H. Mahvi, Decolorisation of Reactive Red 120 Dye by Using Single-Walled Carbon Nanotubes in Aqueous Solutions. Journal of Chemistry 11 (2013) 8. 